\title{
1 Integrative research efforts at the boundary of biodiversity and global change \\ 2 research
}

4 Samuel Abiven ${ }^{1}$, Florian Altermatt ${ }^{2,3}$, Norman Backhaus ${ }^{1}$, Anna Deplazes-Zemp ${ }^{4}$,

5 Reinhard Furrer ${ }^{5}$, Benedikt Korf ${ }^{1}$, Pascal A. Niklaus ${ }^{3}$, Gabriela Schaepman-Strub ${ }^{3}$,

6 Kentaro Shimizu $^{3}$, Debra Zuppinger-Dingley ${ }^{3}$, Owen Petchey ${ }^{3}$, Michael Schaepman ${ }^{1}$

$9{ }^{1}$ Department of Geography, University of Zurich, Zurich, Switzerland

$10{ }^{2}$ Department of Aquatic Ecology, Eawag, Swiss Federal Institute of Aquatic Science and

11 Technology, Dübendorf, Switzerland

$12{ }^{3}$ Department of Evolutionary Biology and Environmental Studies, University of Zurich,

13 Zurich, Switzerland

$14{ }^{4}$ Ethics Research Institute, University of Zurich, Switzerland

$15{ }^{5}$ Department of Mathematics and Department of Computational Science, University of

16 Zurich, Switzerland

18 Corresponding author: Samuel Abiven

19 Samuel.abiven@geo.uzh.ch

20 Department of Geography, University of Zurich, Winterthurerstrasse 190, CH-8057

21 Zurich, Switzerland

This document is the accepted manuscript version of the following article: Abiven, S., Altermatt, F., Backhaus, N., Deplazes-Zemp, A., Furrer, R., Korf, B., ... Schaepman, M. E. (2017). Integrative research efforts at the boundary of biodiversity and global change research. Current opinion in Environmental Sustainability, 29, 215-222. https://doi.org/10.1016/j.cosust.2018.04.016 


\section{Abstract}

26 Global environmental change and biodiversity loss are closely linked through different

27 feedback mechanisms. The University of Zurich Research Priority Programme on

28 "Global Change and Biodiversity" approach is to work with interdisciplinarity and

29 transdisciplinarity to integrate mechanisms of interactions, feedback and scale and

30 improve our understanding of the feedbacks between global change and biodiversity

31 effects. Such work across research disciplines is not without its challenges. Here we share

32 some of the questions that arose from our research approach over the last five years and

33 how we addressed these challenges. First, our transdisciplinary approach allows

34 combining different disciplines into a more holistic perspective towards integrative

35 research, but demands collaborative work to establish common terminology, concepts,

36 and metrics. Second, the research theme's common perspective (biodiversity is desirable,

37 global change is not) may also induce a confirmation bias from preconceived ideas.

38 Third, new challenges emerge from scaling mechanisms and feedbacks at different spatial

39 and temporal scales. Fourth, we investigate how to relate biodiversity, global change,

40 ecosystem services and functions using interdisciplinary approaches. Fifth, we identify

41 gaps between existing experiments and data requirements, and propose the definition of

42 new experimental setups by linking processes and performing experiments at typical

43 experimental scales as well as at larger scales. We conclude by emphasising the necessity

44 to integrate theory, experiments, modelling and simulation, high performance computing

45 and big data to understand feedbacks between biodiversity loss and processes of global 46 change. 


\section{Introduction}

49 Biodiversity loss is one of the important processes affected by global change drivers,

50 summarised in the Millennium Ecosystem Assessment as the 'big five': land use change,

51 climate change, invasions, exploitation, and pollution [1]. Biodiversity loss and global

52 change are strongly bound together through feedback mechanisms taking place at spatial

53 and temporal scales that are usually smaller than those currently incorporated in global

54 earth system models [2]. Each of the 'big five' has been shown to negatively impact on

55 biodiversity [3]. However, studying these drivers independently is unlikely to provide a

56 coherent understanding which can be used to predict how global change affects

57 biodiversity and vice versa. These considerations are at the very core of the University of

58 Zurich Research Priority Programme on "Global Change and Biodiversity" (URPP

59 GCB). Within this programme, a multi-disciplinary group, which includes ecologists,

60 geneticists, remote sensing, physical and human geographers, mathematicians and

61 philosophers, collaborates to integrate mechanisms of interactions, feedback and scale to

62 improve the understanding of the feedbacks between global change and biodiversity

63 effects.

64 Because of this diversity of research interests, methodology and conceptual approaches,

65 specific questions on how to address the impact of global change drivers and the

66 feedbacks with biodiversity were discussed in our group. This led to intense

67 transdisciplinary questioning of research directions. Here, we consider transdisciplinarity

68 as our common effort to address scientific problems by differentiating and integrating

69 knowledge from different scientific and societal sources [4]. Whereas including more 
70 scientific disciplines may provide a more holistic vision, it creates new hurdles to

71 overcome. Here, we share some of the challenges that arose from our common work over

72 the last five years, and how we are currently working towards resolving such challenges.

\section{$74 \quad$ Terminology between disciplines}

75 Joint research across disciplines requires a shared vocabulary, and shared understanding

76 of the terminology used in different disciplines. We observed when discussing

77 terminology that consolidating the equivocity of the vocabulary in a given discipline is

78 often a research question in itself [5], and unifying the terminology across large

79 overarching fields seems a major challenge. For example, the biodiversity concept can be

80 based on species richness, however genetic composition or species traits may be included

81 to characterize biodiversity in other interpretations within the same discipline. Others

82 might refer to the varying perceptions and values different people have of biodiversity,

83 for instance, as 'nature's contributions to people' [6,7]. This makes comparisons of results

84 from studies using different terminologies very difficult, sometimes even impossible.

85 There are efforts underway to address this challenge, such as the ongoing selection and

86 definition of essential biodiversity variables, which will assist in harmonizing monitoring

87 biodiversity at global scale [8]. Another approach is to develop ontologies (e.g.[9]). In

88 our research programme we address this challenge with a series of "terminology briefs",

89 where researchers from different disciplines work together towards a common definition

90 of pivotal terms, such as integration, global change or phenology.

91 We further address such transdisciplinarity and multidisciplinarity questions directly

92 within our research programme by combining concepts such as essential biodiversity 
93 variables, earth system processes, ecosystem services and resource frontiers within one

94 integrative framework (fig. 1). Each of the individual projects within the URPP GCB is

95 located within and across the concepts encouraging transdisciplinary approaches on a

96 daily basis $[10,11]$.

98 The positive connotation of biodiversity, the pejorative meaning of global change

99 Biodiversity is mostly perceived positively and as something to be preserved and

100 promoted. In contrast, global change is perceived negatively, a threat, which requires

101 mitigation or adaptation to strengthen resilience, although this framing is contested in the

102 literature [12]. This juxtaposition is well backed up in the literature and it is not our aim

103 to question these positive or negative connotations per se. It is interesting, however, to

104 observe that both the concepts of biodiversity and of global change may suffer from

105 confirmation bias $[13,14]$, i.e. the tendency to favour information in a way that confirms

106 pre-existing predispositions towards a particular framing of these terms. Defining a more

107 careful framing of these two ideas presents a major challenge.

108 Such confirmation biases have an outcome on how experiments are designed, read and

109 analysed; the data collected, and how publications are written. Experimental designs

110 evaluating the effect of global change tend to overestimate the amplitude of the changing

111 drivers [15], whereas biodiversity research tends to focus on the positive effects of a

112 larger, more diverse, number of species [14].

113 A major challenge is therefore to question existing connotations, to be open to all results

114 that fulfil the standards of scientific research although they may not fit into the normative

115 framework, and to be aware of conflicts of interest. This means taking into account the 
116 connotations of the concepts of biodiversity and global change [16]. In our research

117 program, researchers address such a challenge by, for example publishing non positive

118 [17] or contradicting results [18], or having an in-depth ethical reflection on our research

119 topic [19]. To challenge existing paradigms further, we need to understand our

120 motivation for and interests in the research, such as by thinking about how we choose our

121 research areas, subjects of study and how we formulate our research questions.

\section{Links to stakeholders}

124 True transdisciplinarity spans not only different research disciplines but integrates 125 concerned stakeholders into research designs, data collection and policy transfer [20].

126 This gives rise to the question of "governance" [10], firstly governance of the research

127 process, and secondly governance of the process of translating research insights into 128 policy. A global question here is "who is asking and who is addressing the question".

129 Stakeholders are rarely consulted at the initial stage of research when scientific questions

130 are formulated despite the major influence of such questions on the experimental design

131 and observations [21-24]. At the same time, powerful stakeholders partially dictate

132 which studies and infrastructures are selected and promoted for funded projects [21],

133 giving rise to conflicts of interest as a result of political agendas. For example, the

134 attention given to certain organisms may not reflect their importance in the ecosystems.

135 Animal, and to a lesser extent plant, biodiversity loss is highlighted, however 136 microbiomes are much less studied despite their major role in ecosystem functioning. 
138 One clear challenge for future research is to evaluate what role stakeholders, policies and

139 politics should play in the design and outcome of research and how to take this into

140 account. Including practitioners or lay people viewpoints while developing research

141 questions may result in very different knowledge forms (more qualitative and

142 multidimensional but less standardized) than the results of a purely scientific approach, as

143 shown by the involvement of beekeepers in studies about pollination [25]. Integrating the

144 new type of data collected in citizen science [26] is a way to achieve this local and

145 holistic overview. But caution is needed: the global picture of global change, as well as of

146 biodiversity research, may look quite different when applied at a local scale and specific

147 location. Transdisciplinarity research may provide more insights on how research may

148 affect policy and practices. The link between research and conservation programs still

149 needs to be assessed in a more holistic way [27]. Caution is required in the assessment of

150 "efficiency of conservation", as conservation policies often fail because they are designed

151 without taking the livelihoods of local populations into consideration and because

152 different stakeholders have different or conflicting interests in conservation programs

$153 \quad[10,28]$.

154 In our program, we work directly with institutions that link our research with

155 stakeholders. We host the project office of the Future Earth global research project

156 bioDISCOVERY [29], which manages a framework to support biodiversity and

157 ecosystem services for policy and decision making. We lead a project to develop

158 remotely-sensed Essential Biodiversity Variables (rs-enabled EBVs) observing and

159 monitoring key characteristics of global biodiversity (http://www.globdiversity.net/) [30].

160 We lead an outreach project, "Biodiversity means life" (http://biodiversitymeanslife.ch/), 
161 with the aim of creating an active dialogue between scientists and the general public on

162 the topic of biodiversity.

\section{Scaling and feedbacks: from where to where?}

165 Scaling processes and biodiversity in space and time may be one of the most obvious 166 challenge for biodiversity and global change research. One technical and scientific

167 challenge is to scale up processes and feedbacks based on ecosystem functions to the

168 level of ecosystems [31]. Research on modifications of biophysical processes induced by

169 biodiversity change at smaller or larger scales are needed, particularly for the prediction

170 of the dynamics in the long-term [32,33].

171 In our program, we propose a number of strategies to study such issues of scaling. The 172 genetic diversity, the genetic evolution and the dynamics of model organisms, which are

173 widespread globally, could potentially be monitored, for example Arabidopsis sp. or oak

174 (Quercus sp.) for the plant kingdom [34,35]. Local to regional scale biodiversity scoping 175 studies support assessment of scaling processes [36]. Investigating one model species 176 would help our understanding of the cascade of constraints that a plant experiences in 177 different ecosystems with their associated drivers. This would help us to disentangle the 178 major drivers of change at different scales of study.

179 Another approach would be to scale up from manipulative experimental plots to 180 landscape scales. Biodiversity-ecosystem functioning relationships have been established 181 primarily through experimental research at the plot scale. Similar patterns found in plot 182 experiments may be observed at landscape scale [37], although it may be less obvious to 183 detect, because of confounding factors. 
185 Time scales are a challenge as they add new dimensions to the above questions. It is

186 actively studied whether the supply of genetic and epigenetic variation might not be in

187 line with the ecological demand for adaptation as set by the rapid rate of global change

$188[35,38]$. In addition to the existing need to predict evolution over decades, changes in

189 plant phenology triggered by global change highlights the need to scale evolutionary

190 processes to seasons [39]. Furthermore, socio-spatial processes of resource extraction

191 often alter landscapes within very short time scales to dramatic effects, in particular in so-

192 called resource frontiers [40].The interlocking of different time scales highlights the need

193 for current predictive assumptions to be redefined: non-linearity and non-steady states

194 should be increasingly considered when modelling across scales.

196 Integrating new types of data in transdisciplinary studies

197 Following the exploration of several scales by disciplines like remote sensing, 198 transdisciplinary projects need to integrate new types of data, providing unprecedented 199 coverage of biodiversity indicators [41]. Such data may partly solve the spatial 200 representativeness and abundance issues of traditional field-based assessments [42]. 201 However, remote sensing data does have limitations that need to be considered when 202 interpreting results. For example, biodiversity and processes occurring below-ground 203 cannot be measured directly, and the assessment of biodiversity in aquatic systems using 204 remote sensing or other novel approaches such as eDNA [35,43], are only beginning to 205 be fully exploited. The challenge is to reconcile biodiversity considerations at the level of 206 an ecosystem, such as a forest, grassland or freshwater body [44], to mechanisms taking 
207 place at a much smaller scale, such as microbial processes. The unequal access to

208 structured data by all scientists and the heterogeneous spatial distribution of such data,

209 make it a biased source of information to be used with caution [45]. In our program, we

210 try to tackle this point by physically working on a given set of predefined research sites,

211 giving us the chance to connect our data and information consistently, even by using own

212 research practises as part of our scientific approach [46]

213

\section{Relating species traits to ecosystem function and ecosystem services}

215 One overarching challenge is the link between ecosystem services, i.e. the services

216 provided by the ecosystem to human society, and ecosystem functions, i.e. the physical,

217 chemical and biological processes taking place in the ecosystems [47]. The temptation to

218 associate specific functions with measured values of a given service is great, leading to a

219 potential quantification of ecosystem services and thus to their exchangeability or even

220 tradability that is highly problematic [48]. This may provide a means to justify

221 conservation policies, but may also give a partial number-based evaluation of complex

222 services like cultural ecosystem services [49]. It is also important to remember that not all

223 concerns about biodiversity have a functional motivation or rationale, biodiversity is

224 often also associated with intrinsic values or relational values (preferences, principles, or

225 virtues that people associate with relationships) [50]. One way forward may be to then

226 translate traits into functions and predict functions based on traits [51,52].

227 In our project, remote sensing is one of the key discipline we use to link functions and

228 services at large scales by deriving functions from traits [36]. Increasingly, remote

229 sensing is used to link in-situ observations to mechanisms and functions to ecosystem 
230 services [41]. The association between remote sensing and genomics may lead to

231 comprehensive phenotyping and the definition of genetically based phenomes as high-

232 throughput sequencing of RNA (RNA-seq) provides monitoring information for diverse

233 physiological traits such as drought stress, nutrient level and phenology [53]. Combining

234 the spectral analysis of plant canopy reflectance and biogeochemical measurements, such

235 as organic compounds or isotope patterns, may also contribute to linking global services

236 and specific functions of a given ecosystem [54]. In aquatic systems, remote sensing

237 could be used in combination with other monitoring tools such as environmental DNA to

238 identify long-term shifts in community structure due to global change [55].

\section{Defining the next generation of experiments}

241 Most of the challenges described above require the acquisition of new data, structured in

242 a different way to that which already exists: global coverage or at least global

243 representativeness, but capturing processes at local scale, more related to traits and

244 functions, more related to models. We need therefore to define the next generation of

245 experiments, which can be used to extrapolate across temporal and spatial scales with

246 increasing complexity and diversity (Fig. 2). Improved measurements may allow the

247 collection of higher dimensional data across organisational levels, expression states,

248 environmental conditions, and developmental timing [56].

249 In many parts of the different disciplines we are involved with, "proof of concept", i.e.

250 the case study highlighting a concept, has often been preferred to research on the effect

251 size, i.e. a more complete overview, including data contradicting the proposed theory. It 
252 appears also that most existing experimental setups are subject to bias, such as the island

253 effect in global change impact studies [57] or artificial ecosystem mimicking [14].

254 Defining new experimental setups, linking processes and large scale, biogeochemical and

255 -physical function and remote sensing information and ground measurement, which can

256 be directly extrapolated by models, is a new frontier in our research field. To integrate

257 part of these aspects, Schmid et al. [58] have recently proposed guidelines for 258 biodiversity experiments.

260 Along with these new sets of data we need to collect, our transdisciplinary group of 261 researchers requires more comprehensive modelling at every level of the questions

262 linking biodiversity and global change, from processes to ecosystem services predictions $263[59,60]$. The transition from a modelling sand-box to nature could help to define the right

264 type of data one needs, particularly with the aim to coordinate global change drivers and 265 feedbacks and biodiversity evolution. Genetic evolution, phenology or trait distribution 266 prediction in particular may help provide a new outlook on the links between global 267 change feedbacks and biodiversity.

\section{Concluding remarks}

270 Here we present seven challenges related to global change and biodiversity that we 271 experienced as a group of researchers coming from as diverse disciplines as ecology, 272 philosophy, geography and mathematics. We are trying to overcome hurdles like 273 terminology, confirmation bias, link to stakeholders, scaling, ecosystem services cascade 274 or new experimental setup with a series of measures, directly implemented in our 
275 research program. Opportunity costs of working in a transdisciplinary fashion are not

276 evident momentarily, but will pay off in the near future. Still, the key to successful

277 transdisciplinary work involves willingness and the ability to work across disciplinary

278 boundaries, and the capability to understand the limitations of current approaches,

279 expanding them beyond current capabilities.

280

281

282 Acknowledgements

283 This work is supported by the University of Zurich Research Priority Program on "Global

284 Change and Biodiversity". We would like to thank Cornelia Krug for her support and her 285 comments on the manuscript. 
288 References

289 1. Millennium Ecosystem Assessment: Millenium Ecosystem assessments:

$290 \quad$ Ecosystems and human well-being: Synthesis. 2005.

291 2. Urban MC, Bocedi G, Hendry AP, Mihoub J-B, Peer G, Singer A, Bridle JR,

292 Crozier LG, De Meester L, Godsoe W, et al.: Improving the forecast for

293 biodiversity under climate change. Science (80- ) 2016, 353:aad8466-aad8466.

294 3. Tilman D, Clark M, Williams DR, Kimmel K, Polasky S, Packer C: Future

295 threats to biodiversity and pathways to their prevention. Nature 2017, 546:73-

$296 \quad 81$.

297 4. Lang DJ, Wiek A, Bergmann M, Stauffacher M, Martens P, Moll P, Swilling M, 298 Thomas CJ: Transdisciplinary research in sustainability science: Practice, 299 principles, and challenges. Sustain Sci 2012, 7:25-43.

300 5. Loreau M: The Challenges of Biodiversity Science. 2010.

301 6. Díaz S, Pascual U, Stenseke M, Martín-López B, Watson RT, Molnár Z, Hill R, 302 Chan KMA, Baste IA, Brauman KA, et al.: Assessing nature's contributions to 303 people. Science (80- ) 2018, 359:270 LP-272.

304 7. Pascual U, Balvanera P, Díaz S, Pataki G, Roth E, Stenseke M, Watson RT, Başak 305 Dessane E, Islar M, Kelemen E, et al.: Valuing nature's contributions to people: 306 the IPBES approach. Curr Opin Environ Sustain 2017, 26-27:7-16.

307 8. Pereira HM, Ferrier S, Walters M, Geller GN, Jongman RHG, Scholes RJ, Bruford 308 MW, Brummitt N, Butchart SHM, Cardoso AC, et al.: Essential Biodiversity $309 \quad$ Variables. Science (80- ) 2013, 339:277-278. 
310 9. Deans AR, Lewis SE, Huala E, Anzaldo SS, Ashburner M, Balhoff JP, Blackburn

311 DC, Blake JA, Burleigh JG, Chanet B, et al.: Finding Our Way through

312 Phenotypes. PLoS Biol 2015, 13.

313 10. Holm P, Goodsite ME, Cloetingh S, Agnoletti M, Moldan B, Lang DJ, Leemans R, 314 Moeller JO, Buendía MP, Pohl W, et al.: Collaboration between the natural, 315 social and human sciences in Global Change Research. Environ Sci Policy $316 \quad 2013,28: 25-35$.

317 11. Sutherland WJ, Freckleton RP, Godfray HCJ, Beissinger SR, Benton T, Cameron 318 DD, Carmel Y, Coomes DA, Coulson T, Emmerson MC, et al.: Identification of 319100 fundamental ecological questions. $J$ Ecol 2013, 101:58-67.

320 12. Cote M, Nightingale AJ: Resilience thinking meets social theory: Situating 321 social change in socio-ecological systems (SES) research. Prog Hum Geogr $322 \quad 2012, \mathbf{3 6}: 475-489$.

323 13. Hulme M: Reducing the Future to Climate: A Story of Climate Determinism 324 and Reductionism. Osiris 2011, 26:245-266.

325 14. Wardle DA: Do experiments exploring plant diversity-ecosystem functioning 326 relationships inform how biodiversity loss impacts natural ecosystems? J Veg $327 \quad$ Sci 2016, 27:646-653.

328 15. Leuzinger S, Luo Y, Beier C, Dieleman W, Vicca S, Körner C: Do global change 329 experiments overestimate impacts on terrestrial ecosystems? Trends Ecol Evol $330 \quad 2011,26: 236-41$.

331 16. Rudiak-Gould P: "We Have Seen It with Our Own Eyes": Why We Disagree 332 about Climate Change Visibility. Weather Clim Soc 2013, 5:120-132. 
333 17. Schmidt H-P, Kammann C, Niggli C, Evangelou MWH, Mackie K a., Abiven S:

334 Biochar and biochar-compost as soil amendments to a vineyard soil:

335 Influences on plant growth, nutrient uptake, plant health and grape quality.

336 Agric Ecosyst Environ 2014, 191:117-123.

337 18. Maestrini B, Nannipieri P, Abiven S: A meta-analysis on pyrogenic organic

338 matter induced priming effect. GCB Bioenergy 2014, doi:10.1111/gcbb.12194.

339 19. Deplazes-zemp A: Commutative Justice and Access and Benefit Sharing for

$340 \quad$ Genetic Resources. Ethics, Policy Environ 2018, 85:1-17.

341 20. Bennett NJ, Roth R, Klain SC, Chan KMA, Clark DA, Cullman G, Epstein G,

342 Nelson MP, Stedman R, Teel TL, et al.: Mainstreaming the social sciences in

343 conservation. Conserv Biol 2017, 31:56-66.

344 21. Schimel D, Keller M: Big questions, big science: meeting the challenges of

345 global ecology. Oecologia 2015, 177:925-34.

346 22. Mauser W, Klepper G, Rice M, Schmalzbauer BS, Hackmann H, Leemans R,

347 Moore H: Transdisciplinary global change research: The co-creation of

348 knowledge for sustainability. Curr Opin Environ Sustain 2013, 5:420-431.

349 23. Darvill R, Lindo Z: Quantifying and mapping ecosystem service use across

$350 \quad$ stakeholder groups: Implications for conservation with priorities for cultural

$351 \quad$ values. Ecosyst Serv 2015, 13:153-161.

352 24. Sténs A, Bjärstig T, Nordström EM, Sandström C, Fries C, Johansson J: In the eye

353 of the stakeholder: The challenges of governing social forest values. Ambio

$354 \quad 2016, \mathbf{4 5}: 87-99$.

355 25. Maderson S, Wynne-Jones S: Beekeepers' knowledges and participation in 
pollinator conservation policy. J Rural Stud 2016, 45:88-98.

357 26. Chandler M, See L, Copas K, Bonde AMZ, López BC, Danielsen F, Legind JK,

358 Masinde S, Miller-Rushing AJ, Newman G, et al.: Contribution of citizen science towards international biodiversity monitoring. Biol Conserv 2017, 213:280294.

361 27. Egoh B, Rouget M, Reyers B, Knight AT, Cowling RM, van Jaarsveld AS, Welz A: Integrating ecosystem services into conservation assessments: A review. Ecol Econ 2007, 63:714-721.

364 28. Kelly AB: Conservation practice as primitive accumulation. J Peasant Stud 2011, 38:683-701.

366 29. Krug C, Teeffelen A van, B.N. BS, Schmid B, Obura D, Metzger JP, Cavender-

Bares J, Shannon L, Schaepman ME, Yasuhara M, et al.: Observations,

371 30. Pettorelli N, Wegmann M, Skidmore A, Mücher S, Dawson TP, Fernandez M, 372 Lucas R, Schaepman ME, Wang T, O'Connor B, et al.: Framing the concept of 373 satellite remote sensing essential biodiversity variables: challenges and future 374 directions. Remote Sens Ecol Conserv 2016, 2:122-131.

375 31. Petchey OL, Pontarp M, Massie TM, Kéfi S, Ozgul A, Weilenmann M, Palamara GM, Altermatt F, Matthews B, Levine JM, et al.: The ecological forecast horizon, and examples of its uses and determinants. Ecol Lett 2015, 18:597611. 
379 32. Zeng Z, Piao S, Li LZX, Zhou L, Ciais P, Wang T, Li Y, Lian X, Wood EF,

$380 \quad$ Friedlingstein $\mathrm{P}$, et al.: Climate mitigation from vegetation biophysical

381 feedbacks during the past three decades. Nat Clim Chang 2017, 7:432-436.

382 33. Smith NG, Dukes JS: Plant respiration and photosynthesis in global-scale

383 models: Incorporating acclimation to temperature and CO2. Glob Chang Biol

$384 \quad 2013, \mathbf{1 9}: 45-63$.

385 34. Jetz W, Cavender-Bares J, Pavlick R, Schimel D, Davis FW, Asner GP, Guralnick

$386 \quad \mathrm{R}$, Kattge J, Latimer AM, Moorcroft P, et al.: Monitoring plant functional

387 diversity from space. Nat Plants 2016, 2:16024.

388 35. Yamasaki E, Altermatt F, Cavender-Bares J, Schuman MC, Zuppinger-Dingley D,

389 Garonna I, Schneider FD, Guillén-Escribà C, van Moorsel SJ, Hahl T, et al.:

$390 \quad$ Genomics meets remote sensing in global change studies: monitoring and

391 predicting phenology, evolution and biodiversity. Curr Opin Environ Sustain

$392 \quad 2017,29: 177-186$.

393 36. Schneider FD, Morsdorf F, Schmid B, Petchey OL, Hueni A, Schimel DS,

394 Schaepman ME: Mapping functional diversity from remotely sensed

395 morphological and physiological forest traits. Nat Commun 2017, 8:1441.

396 37. Oehri J, Schmid B, Schaepman-Strub G, Niklaus P: Biodiversity promotes

$397 \quad$ primary productivity and growing season lengthening at the landscape scale.

$398 \quad$ 2017, doi:10.1073/pnas.1703928114.

399 38. Kokko H, Chaturvedi A, Croll D, Fischer MC, Guillaume F, Karrenberg S, Kerr B,

$400 \quad$ Rolshausen G, Stapley J: Can Evolution Supply What Ecology Demands?

$401 \quad$ Trends Ecol Evol 2017, 32:187-197. 
402 39. Garonna I, de Jong R, de Wit AJW, Mücher C a, Schmid B, Schaepman ME:

403 Strong contribution of autumn phenology to changes in satellite-derived

404 growing season length estimates across Europe (1982-2011). Glob Chang Biol

$405 \quad 2014$, doi:10.1111/gcb.12625.

406 40. Li TM: What is land? Assembling a resource for global investment. Trans Inst

$407 \quad$ Br Geogr 2014, 39:589-602.

408 41. Braun D, Damm A, Paul-Limoges E, Revill A, Buchmann N, Petchey OL, Hein L,

409 Schaepman ME: From instantaneous to continuous: Using imaging

410 spectroscopy and in situ data to map two productivity-related ecosystem

$411 \quad$ services. Ecol Indic 2017, 82:409-419.

412 42. Vellend M, Baeten L, Myers-Smith IH, Elmendorf SC, Beausejour R, Brown CD,

413 De Frenne P, Verheyen K, Wipf S: Global meta-analysis reveals no net change

414 in local-scale plant biodiversity over time. Proc Natl Acad Sci 2013, 110:19456-

41519459.

416 43. Deiner K, Fronhofer EA, Mächler E, Walser J-C, Altermatt F: Environmental

417 DNA reveals that rivers are conveyer belts of biodiversity information. Nat

$418 \quad$ Commun 2016, 7:12544.

419 44. Dudgeon D, Arthington AH, Gessner MO, Kawabata Z-I, Knowler DJ, Lévêque C, 420 Naiman RJ, Prieur-Richard A-H, Soto D, Stiassny MLJ, et al.: Freshwater

421 biodiversity: importance, threats, status and conservation challenges. Biol Rev $422 \quad 2006,81: 163$.

423 45. Bezuidenhout LM, Leonelli S, Kelly AH, Rappert B: Beyond the digital divide:

424 Towards a situated approach to open data. Sci Public Policy 2017, 44:464-475. 
425 46. Deplazes-Zemp A, Abiven S, Schaber P, Schaepman ME, Schaepman-Strub G,

426 Schmid B, Shimizu K, Altermatt F: The Nagoya Protocol could backfire on the

427 Global South. Nat Ecol Evol [date unknown],

428 47. Harrison PA, Berry PM, Simpson G, Haslett JR, Blicharska M, Bucur M, Dunford

429 R, Egoh B, Garcia-Llorente M, Geamon N, et al.: Linkages between biodiversity

$430 \quad$ attributes and ecosystem services: A systematic review. Ecosyst Serv 2014,

$431 \quad 9: 191-203$.

432 48. Spangenberg JH, Settele J: Precisely incorrect? Monetising the value of

$433 \quad$ ecosystem services. Ecol Complex 2010, 7:327-337.

434 49. Gómez-Baggethun E, de Groot R, Lomas PL, Montes C: The history of

435 ecosystem services in economic theory and practice: From early notions to

436 markets and payment schemes. Ecol Econ 2010, 69:1209-1218.

437 50. Chan KMA, Balvanera P, Benessaiah K, Chapman M, Díaz S, Gómez-Baggethun

438 E, Gould R, Hannahs N, Jax K, Klain S, et al.: Opinion: Why protect nature?

439 Rethinking values and the environment. Proc Natl Acad Sci 2016, 113:1462-

$440 \quad 1465$.

441 51. Laureto LMO, Cianciaruso MV, Samia DSM: Functional diversity: An overview

442 of its history and applicability. Nat e Conserv 2015, 13:112-116.

443 52. Schweiger AK, Schütz M, Risch AC, Kneubühler M, Haller R, Schaepman ME:

444 How to predict plant functional types using imaging spectroscopy: linking

445 vegetation community traits, plant functional types and spectral response.

$446 \quad$ Methods Ecol Evol 2017, 8:86-95.

447 53. Cavender-Bares J, Meireles JE, Couture JJ, Kaproth MA, Kingdon CC, Singh A, 
Serbin SP, Center A, Zuniga E, Pilz G, et al.: Associations of leaf spectra with genetic and phylogenetic variation in oaks: Prospects for remote detection of biodiversity. Remote Sens 2016, 8.

451 54. Cavender-bares J, Polasky S, King E, Balvanera P: A sustainability framework for assessing trade-offs in ecosystem services. 2015, 20.

453 55. Jackson MC, Weyl OLF, Altermatt F, Durance I, Friberg N, Dumbrell AJ, Piggott JJ, Tiegs SD, Tockner K, Krug CB, et al.: Recommendations for the Next

56. Dhondt S, Wuyts N, Inzé D: Cell to whole-plant phenotyping: The best is yet to come. Trends Plant Sci 2013, 18:1360-1385.

459 57. Leuzinger S, Fatichi S, Cusens J, Körner C, Niklaus PA: The "island effect" in 460 terrestrial global change experiments: a problem with no solution? AoB Plants 2015, 7:plv092.

462 58. Schmid B, Baruffol M, Wang Z, Niklaus PA: A guide to analyzing biodiversity 463 experiments. J Plant Ecol 2017, 10:91-110.

464 59. Nelson E, Mendoza G, Regetz J, Polasky S, Tallis H, Cameron DR, Chan KMA, 465 Daily GC, Goldstein J, Kareiva PM, et al.: Modeling multiple ecosystem services, biodiversity conservation, commodity production, and tradeoffs at landscape scales. Front Ecol Environ 2009, 7:4-11.

468 60. Thuiller W, Albert C, Araújo MB, Berry PM, Cabeza M, Guisan A, Hickler T, 469 Midgley GF, Paterson J, Schurr FM, et al.: Predicting global change impacts on plant species' distributions: Future challenges. Perspect Plant Ecol Evol Syst 


\section{Featured articles}

477 * Harrison, P.A., Berry, P.M., Simpson, G., Haslett, J.R., Blicharska, M., Bucur, M., 478 Dunford, R., Egoh, B., Garcia-Llorente, M., Geamon, N., Geertsema, W., 479 Lommelen, E., Meiresonne, L., Turkelboom, F., 2014. Linkages between 480 biodiversity attributes and ecosystem services: A systematic review. Ecosystem $481 \quad$ Services 9, 191-203. doi:10.1016/j.ecoser.2014.05.006

482 This literature review links biodiversity characteristics and traits to a selection of 483 ecosystem services. It shows several positive relationships, but also the complexity 484 of the interactions between the biodiversity and the service provision.

485 * Chan, K.M.A., Balvanera, P., Benessaiah, K., Chapman, M. \& Díaz, S., 2016. Why 486 protect nature? Rethinking values and the environment. PNAS, 113(6), pp.1462$487 \quad 1465$.

488 This opinion paper is linking environmental policy, nature protection and values 489 associated to nature. It is reframing the discussion about instrumental and relational $490 \quad$ values.

491 * Chandler, M., See, L., Copas, K., Schmidt, A., Claramunt, B., Danielsen, F., Legrind, 492 J., Masinde, S., Miller Rushing, A.; Newman, G., et al., 2016. Contribution of 493 citizen science towards international biodiversity monitoring. Biological 
Conservation. doi:10.1016/j.biocon.2016.09.004

495 This article shows the use of citizen science to assess the essential biodiversity variables.

496 It explores what can be learnt from successful experiences.

497 ** Pereira, H.M., Ferrier, S., Walters, M., Geller, G.N., Jongman, R.H.G., Scholes, R.J., 498 Bruford, M.W., Brummitt, N., Butchart, S.H.M., Cardoso, A.C., Coops, N.C., 499 Dulloo, E., Faith, D.P., Freyhof, J., Gregory, R.D., Heip, C., Höft, R., Hurtt, G., Jetz, 500 W., Karp, D.S., McGeoch, M.A., Obura, D., Onoda, Y., Pettorelli, N., Reyers, B., 501 Sayre, R., Scharlemann, J.P.W., Stuart, S.N., Turak, E., Walpole, M., Wegmann, M., 502 2013. Essential Biodiversity Variables. Science 339, 277-278. 503 doi:10.1126/science. 1229931

504 This article describes the basis of a harmonized monitoring of biodiversity at global scale.

505 It defines the theoretical background of such effort, but put it also into practice.

$506 * *$ Wardle, D.A., 2016. Do experiments exploring plant diversity-ecosystem functioning 507 relationships inform how biodiversity loss impacts natural ecosystems? Journal of $508 \quad$ Vegetation Science 27, 646-653. doi:10.1111/jvs.12399

509 This article questions point by point the validity of the biodiversity experiments as 510 developed until now. It addresses specifically the question about the analogy between 511 these experiments and the "real" ecosystems. 